\title{
DEMAND FOR FRIGATE ON RHODES ISLAND
}

Rodos Adası'nda Fırkateyne Rağbet

\section{Arzu BAYKARA TAŞKAYA*}

\section{ABSTRACT}

The frigate was the most common type of ship constructed on Rhodes Island in the $19^{\text {th }}$ century. We know that these ships were generally constructed by the administrators of the region, which were necessary for the navy for Istanbul. The ships constructed for Istanbul had to be finished and sent in a certain period of time. For this reason, it was requested in the documents to complete the shipbuilding as soon as possible. Undoubtedly, the most important person involved in shipbuilding was the Mütesellim Murâbıtzâde Captain Hasan. The state trusted this person, who also carried out several duties with him, and he was very useful in the construction of galleons and frigates for the Mütesellim Yusuf Bey served at the state level after the Mütesellim Murâbıtzâde Captain Hasan, we also see that this person had successfully completed the construction of many frigates. These people, who were personally responsible for the construction of many ships in different periods, had the ships constructed for the army. In article, which we wrote using archival documents, how the change in ship technology was reflected in shipbuilding; with the help of the aid received from Istanbul, we tried to trace the archival documents, under which conditions the shipbuilding took place at the maximum capacity that could be done on the island of Rhodes, which was a large-scale island, and how the people had a significant economic power with this business capacity created on the island.

Keywords: Rhodes Island, frigate, shipbuilding, shipyard, Mütesellim Murâbıtzâde Captain Hasan.

\section{öz}

19. yüzyılda Rodos Adası'nda en fazla yapılan gemi tipi fırkateyndir. Genellikle İstanbul için donanmaya gerekli olan gemilerin bölgenin idarecileri tarafından inşa edildiğini biliyoruz. İstanbul için inşa edilen gemiler, belli sürede bitirilip gönderilmek zorundaydı. Bunun için belgelerde bir an evvel gemi yapımının tamamlanması istenmiştir. Gemi inşasında görev yapan en önemli şahıs Mütesellim Murâbıtzâde Hasan Kaptan'dır. Birkaç görevi de beraberinde yapan bu şahsa, devlet oldukça itimat

\footnotetext{
${ }^{*}$ Assist. Prof. Dr., Dumlupınar University, Vocational School of Social Sciences, Kütahya/Turkey. E-mail: a.baykara20@gmail.com. ORCID: 0000-0002-1712-4881.
} 
etmiş ve şahsın devlet için kalyon ve fırkateyn inşasında oldukça yararlılıkları görülmüştür. Mütesellim Yusuf Bey de Mütesellim Murâbıtzâde Hasan Kaptan sonrasında devlet kademesinde görev yapmıştır. Bu şahsın da birçok fırkateyn inşasını başarıyla tamamladığını görüyoruz. Farklı dönemlerde birçok geminin yapılmasından bizzat sorumlu bu kişiler ordunun ihtiyacı olan gemileri inşa ettirmiştir. Arşiv belgelerinden yararlanarak yapılan bu çalışmada gemi teknolojisindeki değişimin gemi imaline nasıl yansıdığını; İstanbul'dan alınan yardımların da etkisiyle büyük ölçekli bir ada olan Rodos Adası üzerinde yapılabilecek maksimum kapasitede gemi inşasının ne koşullarda gerçekleştiğini, adada yaratılan bu iş kapasitesiyle halkın ekmek kapısı olarak önemli bir ekonomik güce nasıl sahip olduğunu arşiv belgelerinin izinde vermeye çalıştık.

Anahtar Sözcükler: Rodos Adası, fırkateyn, gemi inşası, tersane, Mütesellim Murâbıtzâde Hasan Kaptan.

\section{Introduction}

Rhodes is one of the largest islands in the Mediterranean. Its name remembered as a place of exile (kalebent) in the Ottoman Empire (işbilir, 2016: 5-7). We know that in the reign of Suleiman the Magnificent (15201566), Eyalet (province) of the Archipelago (Eyalet-i Cezayir-i Bahr- $i$ Sefid) and this province was first established in the time of Suleiman the Magnificent (1520-1566) in 1553 by adding Kocaeli, Sığla, Biga from the Eyalet of Anatolia, Eğriboz, Inebahtı, Mezistre, Karlıeli from Eyalet of Rumelia and Lesbos Sanjaks. The boundaries of this province had differed over time (Ünal, 2002: 251-261; Ünen, 2013). Social and economic researches had been carried out about the nineteenth century Rhodes Island before (Ünen, 2013; Baykara Taşkaya, 2021). Rhodes Island was one of the most important places where the state constructed ships. On the island where galleons and frigates were densely constructed, the shallowness of the harbor increased the interest in frigates, which were smaller than the galleon. The structure of the change in ship technology in the thirty year period that we examined on the island from 1790 to 1828 was also given. Although there were different types of ships constructed on the island apart from the ship type frigate described here, we have limited our subject only to this type of ship. In this article, we will mention about the shipbuilding in Rhodes Island following the documents found in the Prime Ministry Ottoman Archives, which is affiliated to the Presidency of the State Archives of the Republic of Turkey. While explaining the shipbuilding, the close relationship of the island with Rumelia and Istanbul; the transportation possibilities of the island and the organization of the tradesmen on the island were explained; 
detailed information about the social and economic situation of the Ottoman Empire is also given. While the shipbuilding works are being explained, the social and economic structure is also explained in detail.

\section{Shipbuilding in the Ottoman Empire}

The epicenter of the Ottoman navy, which gained a fundamental organization in parallel with the expansion of the state in the $16^{\text {th }}$ century, was The Imperial Arsenal (Tersâne-i Âmire). It is known that the Ottoman Empire had shipbuilding dockyards and constructed ships in suitable ports and coasts on the Black Sea, Marmara, Aegean and Mediterranean coasts from the earliest times.

The galley was the archetypal warship of the Ottoman navy in the $16^{\text {th }}$ and most of the $17^{\text {th }}$ century. The galley measures 40 to 42 meters in length 5.5 meters in width and has draught of two meters (Guilmartin, 2010: 116118). Galleon was used by the British, the Dutch and the Barbary corsairs in the Mediterranean, the most widespread type of this vessel had a hulllength of 30 to 35 meters and a width of 9 to 12 meters (Guilmartin, 2010: $172-176)$. From the beginning of the $18^{\text {th }}$ century, the British tried to develop the galleon; at the end of this century galleys were widespread in the Mediterranean Countries. A deep-rooted tradition in the Mediterranean dating back to Roman times is the "tall ship" galley equipped with oars. On the contrary, galleons, with their sails, created a kind of division of labor in the class of "round ships". The galley was used as a warship, and the galleon was mostly used for trade (Cipolla, 2003: 40).

Among the sailboats that stood out in the 15-17 centuries, the fire ship, Ağrıpar, Barça, galleon (Bostan, 2004: 65, 86; Bostan, 2020: 223), frigate were the ships that were widely used. Among these, the frigate was the most constructed ship type in Rhodes (Uzunçarşılı, 1988: 467). Frigates with single-locker and three-masted sailing warships smaller than galleons, were specified as "frikatun" in the Rûznâme of Selim III and in the history of Câbî. Frigate lengths ranged from 34 to 41.5 meters. The number of the cannons varied from thirty to seventy. Frigates that did not have cannon on their deck were called "meze frigates". Since the "firkate", which was used in the Ottoman navy and moved with oars, and the ship called "frigate" by the Europeans, were confused with each other, the Ottomans changed the word to the sailing ship, partially breaking the word, and called it "firkateyn" (Arıkan, 1993: 28; Cabi Ömer Efendi, 2003: 103). In the early times, the Ottomans not only engaged in maritime activities in the ports of Gemlik 
and Izmit, but also benefited from the Anatolian Beyliks, such as Karesi, Saruhan, and Aydın shipyards. These shipyards were important due to the fact that they had beaches for shipbuilding, but; they were not in a position to give the service of the ship's workbench and to both build and equip a ship with all its supplies. However, the dockyards in these places were used to build boats. Frigates were important ships. These ships had 10-17 seats and two or three people pulled each oar. They took an average of 80 navy soldiers each, and there were also seventy people, including officers, servants and stagers. The name of this type of ship was called "pergende". Pergendes had 18-19 seats. Another boat that was larger than pergendes called "kalite" and it had 19-24 seats (Kalyota-Galyot). Pergendes and kalites were used for tracking and had cannons. The largest of this type of ship was the galleon (Bostan, 2005: 390; Cezar, 1959: 1520). Thanks to the efforts of the "Kapudan Pasha" (grand admiral) Cezayirli (Algerian) Gazi Hasan Pasha, the "Tersâne-i Âmire Mühendishanesi" (The Imperial Arsenal Engineering School) was opened under the name of "Hendesehane" in 1775 (Beydilli, 1995: 23). In the Ottoman Empire, galleons were regularly constructed in the shipyards in the Black Sea and Aegean Sea, especially in The Imperial Arsenal in Istanbul.

Despite the reform movements initiated after the Battle of Lepanto in 1571, not much progress could be made in this regard in the traditional world of the Ottoman Empire (Gencer, 2001: 59). In the $16^{\text {th }}$ century, the arsenal experienced its first peak of activity, notably during the period subsequent to the Battle of Lepanto where the great majority of the fleet was either destroyed or captured (Panzac, 2009: 22). After the Çeşme Catastrophe in 1770, we see that the arms were rolled up for the shipyard facility (Bostan, 2009: 16). Another important attempt made by Selim III (17891808) to reorganize the Ottoman navy was to reconsider the provincial shipyards and shipbuilding dockyards, which were suitable for shipbuilding outside of Istanbul, but were not given much importance (Özkaya, 1985: 54; Bostan, 1999: 619). Understanding the necessity of reform in the country, Selim III took ideas from the prominent dignitaries of the state for the administration of the country. While the shipyards of the country such as The Imperial Arsenal namely Imperial Shipyard, Sinop, Kos, Rhodes and the surrounding areas mentioned in the report given to the Sultan in 1791 by the prominent dignitaries, was full of warships constructed in, but it was reported that they were deprived of equipment such as cannon, cannonball and ammunition and required measures to be taken. In 1795, during the reign of 
Selim III, a large galleon was constructed at the Golden Horn Shipyard by the French naval engineer Le Bon. In addition, the Mesudiye galleon was constructed and launched into the sea. Bron and Benois, who were French naval engineers, with the participation of a Swedish engineer Klintberg and two Turkish architects, embarked on a reform movement that would include 15 shipyards with the permission of the Sultan. The idea of building a large dock in The Imperial Arsenal and construction ships suitable for the conditions of the age was dominant (Bostan, 1992: 69-100). The inadequacy of the financial situation and the poor current situation did not bring any results about this (Çetin, 2002: 814). As a result of this, a determination was made for the provincial shipyards located on the islands and on the Black Sea coast and the unsuitable ones were quickly made suitable for shipbuilding. As a part of the reforms, seafaring activities and the personal structure in particular were systematized. A treasury of Naval Affairs was created to finance all naval activities. As of 1792-93, the method of sheathing the hulls and bottoms of the ships with copper to protect them against wood-eating worms and the other harmful water creatures and to increase sailing speed was brought to the fore. The first Ottoman dry dock was built on the Golden Horn by the Swedish engineers; "lengerhane" and "endezahane" workshops were created in which anchors were manufactured and ship draughts were designed. The new mast machines for fitting the masts in their places and pumps and fire conduits, as well as a new ship launching method were adopted, the first logbooks were introduced to the ships, a centralized kitchen and provisioning system was implemented aboard the ships (Zorlu, 2009: 41).

Galleons and frigates were constructed in shipyards such as Gemlik, Kale-i Sultaniye, Lemnos, Lesbos, Samos, Bodrum, Rhodes, Antalya, Bendereğli, Sinop, and Sukhum. While developments were achieved in the maritime field during the reigns of Mahmut II and Abdulaziz, it was interrupted during the reign of Abdulhamid II (Arı, 2009: 125-145; Batmaz, 2009: 159173). Torpedoes and torpedo boats emerged as the fundamental element of Abdulhamid's naval policy. Not only 24 torpedo boats were commissioned between the years of 1883 and 1906, but also tens of similar vessels were purchased during his reign.

\section{Shipbuilding on Rhodes Island}

Ships were constructed illegally in many places without establishing a shipyard on Rhodes Island; we see that the state wanted to prevent them. The people, on the other hand, wanted a shipyard to be constructed, as 
they saw it as a business gateway. In the document dated 22 August 1848 (Hijri 22 Ramadan 1264), in the investigation made by Commander Mashuk Pasha in the places connected to Eyalet (province) of the Archipelago which were Kos and Rhodes Islands in the Mediterranean, and all regions connected to Rhodes, in the investigation conducted by Commander Mashuk Pasha, at first it was requested that parliament be established on Symi Island and that the books kept by ensuring the participation of persons from foreign countries be recorded. Mashuk Pasha tried to maintain control with the assemblies formed in Kashot, Kalimnoz, Leryoz Paniziz Islands; while some island councils were canceled; he specifically wanted the consuls to participate in these assemblies. Kapudan Pasha (grand admiral) Mehmet Ali Pasha reported that many unlicensed ships were constructed in the censuses he gave regarding the island and that there was no other inappropriate situation (Document-1). The start of operation of the shipyard on the island took control of shipbuilding and revitalized the workforce. In the document dated 8 December 1850 (3 Safar 1267), written to the Governor of the Archipelago, it was emphasized that the people of Rhodes suffered from poverty, they wanted to work in shipbuilding as a business opportunity, they asked a shipyard to be established on the island and a shipbuilding license to be given and a reduction in the taxes of the people of Rhodes was also emphasized (Document-2). In the document dated the first month of 1789, it was requested to purchase a large amount of tar from some places and to send this equipment quickly over the mobilized rater for the shipyard. A letter was sent to the Chief Accountant with "derkenar" to give a total of 3000 kurus of money for this situation (Document-3).

On June 4, 1792 (13 Shawwal 1206), a report was sent for the preparation of 500 double-circular logs (holes) in Thessaloniki, required for the gun mounts for a large galleon in the shipyard, and of the frigates in Rhodes and the galleons constructed in the surrounding areas. While requesting a bailiff from the region for this job; The Imperial Arsenal was informed about this appointment from the surrounding areas. While some advance was given for this work; and it was also reported the process for cutting timber to start as soon as possible and the preparation of the equipment to be done for Thessaloniki Pier after the cutting was finished. Ships were sent to the region for the loading of the goods (Document-4). We can see from the documents that timber was procured from Rumelia for the ships to be constructed. In the document dated September 1792 (18 Muharram 1207), it was requested that the axe man and lumber man be assigned for the tim- 
ber to be cut from the districts of Thessaloniki for the large galleons and frigates to be constructed in Rhodes and other neighborhoods; from Thessaloniki District 125 pieces, from Karakarye District 100 pieces; from Yenice District 100 pieces, from Vilad District 100 pieces and from Avar District 50 pieces of timber were requested; in order to get the shares of the districts to as soon as possible, the people of the mentioned places were called to duty. In the provision written to the Mutasarrıf of Thessaloniki and to its districts, information was given about the transportation of the goods to the pier (Document-5). It was requested that 5000 pieces of large elm and oak timber, known as the long rod, required for the cannon mounts of the galleons and frigates being constructed in the shipyard, in Rhodes and in the surrounding areas, were loaded to large ships by the porter and also it was requested to collect the necessary equipment from the forests of Thessaloniki immediately (Document-6). We see that equipment wasn't available on the island, especially iron and iron-related products, were outsourced. In the document dated August 7, 1793 (29 Zilhijce 1207), it was ensured that the 1000 shoreline bullets required for the lead boards to be poured for the gomana holes of the galleon constructed in the shipyard and the frigate that was constructed on Rhodes Island and came to the shipyard, were supplied from arsenal (Cephane-i Âmire) (Document-7).

We see that shipbuilding works were being carried out in more modern conditions. In the document dated October 13, 1792 (26 Safar 1207), it was stated that ships made of iron nails and bolts were quite heavy and also using too much iron caused cost; it was stated that the nail called "Kavila" obtained from the pirnar tree was used in foreign countries because iron rots the ships. Wooden nails were recommended to be used on ships being constructed in Rhodes, where screws provided a strong hold on the ship with intermittent tapping. ${ }^{1}$ A provision was sent from The Imperial Arsenal to ensure the transportation of wooden nails made from the cut trees selected from the Mekri (Fethiye) District as soon as possible. More than 30 thousand pieces of pirnar trees, which were cut every year by the traders and sent to the surrounding areas, to be given to the Mütesellim of Rhodes Murâbitzâde Captain Hasan, a person assigned to this task transferred it from Mekri Pier to the island (Document-8).

We see that most of the architects \& engineers required for construction in the region were chosen among from non-Muslims or foreigners. In

\footnotetext{
1 "Kavila" is a wooden nail used to bind wooden pieces together in carpentry.
} 
some cases, certain privileges had been requested for the skill of these individuals. In the document dated 27 July 1794 (28 Zilhijce 1208), named Antuvan Veledi Yularoh, the architect of the ships constructed on Rhodes Island for several years, was asked to be forgiven from the "cizye" tax (Erkal, 1993: 42) due to his scientific skills in architecture. ${ }^{2}$ It was stated that the situation was admirable so that would be asked to the Sultan. But in the sent document, no exemption was provided; and "fermanı alişan" was given to architecture (Document-9).

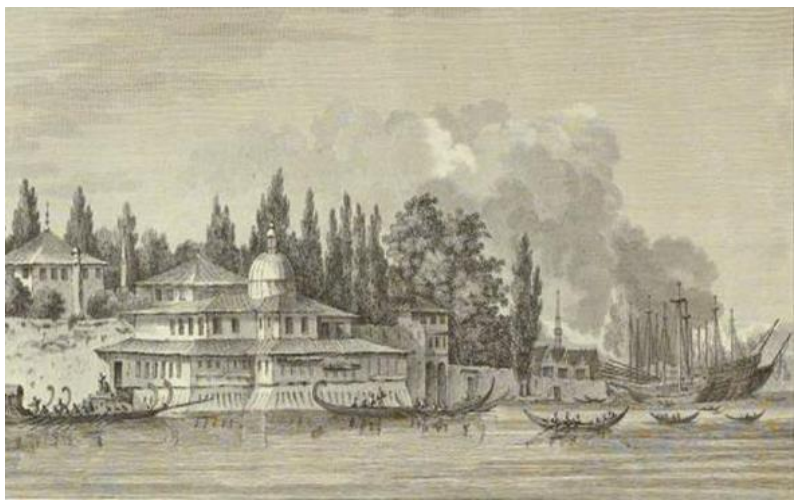

Picture 1. Imperial Arsenal at Gallipoli (Melling ,1819: 40).

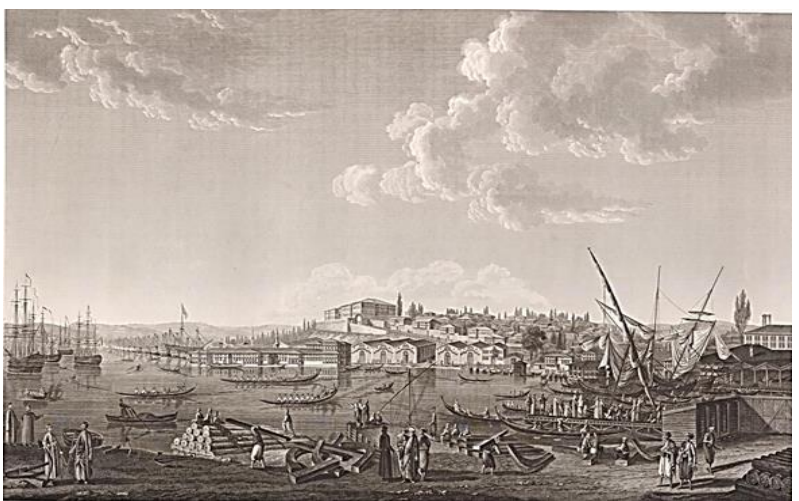

Picture 2. Ottoman Navy at Aynalıkavak (Choiseul-Gouffier, 1782: 482).

Sometimes we see that normal citizens also had ships constructed. In the document dated October 7, 1820 (29 Dhu al-Hijjah 1235), "zimmi" named Yakublalık of Rhodes, who was constructing two frigates on Rhodes, it was ensured that the ships launched after the completion. It was requested to give 90 coin daily money from the money accumulated from

2 "Cizye" is the head tax levied on the men of non-Muslim subjects in the Islamic state. 
Rhodes customs goods to that person; Captain Pasha was given the necessary information about the situation (Document-10).

We see that the governors also had ships constructed in Rhodes Island. A ship constructed by the Governor of Egypt, served the Ottoman navy during the Greek Revolt. Greeks, who provided all kinds of cultural and economic support for independence, started a rebellion in Morea in 1821. The ships constructed in the shipyards of Rhodes area served the army at a time when the Greek Revolt broke out. In the document dated 25 August 1824 (29 Zilhijce 1239), it was reported that the frigate constructed in Rhodes reached Alexandria on 2 November. More than 304 workers started to complete the missing parts of the ship under the command of Mehmet Ali Pasha. It is reported that ibrahim Pasha was about to depart from Alexandria with the Egyptian fleet; The navy, which came to the front of ipsare Island with 60 pieces of navy, was involved in the war with Captain Pasha (Document-11).

We also see that there were not enough tradesmen to work in the shipyard on Rhodes Island. Five years later again, the same person reported that there was not enough workers on the island for the frigate, which was being constructed, to be finished faster. It had been stated that there had been a request for the completion of the frigate regarding the situation for a long time, and a notification had been made to the Chief Accountant to send carpenter and auger workers from Anatolia and other islands. It had been reported that the workers working in the construction of the galleon that was being constructed in the Bodrum District could be supplied from this without any restrictions; although labor was requested from other regions, it had been reported that it was not suitable for that time (Document-12). It had been reported that the workers working in the construction of the galleon that was being constructed in Bodrum District could be used without any restrictions; it had been reported that it was not appropriate to ask for labor from other regions at the moment of time (Document-12).

In the document dated 3 December 1825 (21 Rebiül Ahir 1241) for a frigate ship being constructed by Mutasarrıf Mehmet Şükrü Bey, one of the "Dergah-ı Âlî Kapıcı", in the Rhodes area, it was stated that 30 thousand kurus to be given to his workers as a daily wage, and 20 thousand kurus for the merchant's embassy, and a total of 50 thousand kurus was sent to the Chief Accountant had been reported (Document-13). In the document dated August 17, 1830 (27 Safer 1246), it was stated that the 1300,5 scales of iron demanded for the frigates constructed in Rhodes was sent from The 
Imperial Arsenal immediately and that the ship would be launched and sent to the Shipyard by means of these equipment. ${ }^{3}$ Apart from this, 7800 scales of raw iron and 299,5 scales of iron were requested. The workers, whose number was increased for the completion of the ships worked day and night, engaged in a feverish work again, the need for equipment such as iron shovels, ammunition, lumber of "felenk" and "uskafi" required for launching the ship was reported to the center. From the Mutasarrif of Rhodes, Mehmet Şükrü Bey, a notification was made to "Sadaret" that the workers accelerated the work (Document-14). During the launching of the ship, the Bosporus traffic was also taken under control. In the document dated 18 July 1832 (19 Safer 1248), it was reported as the $15^{\text {th }}$ day of Muharram in 1248 with the completion of this frigate constructed in Rhodes. It was also reported that ship traffic in the Bosporus was taken under control by the navy with its commanding officer captain pasha and the ship was transferred to the big port and it had been reported that the equipment required for launching was being tried to be completed (Document-15). With the establishment of the shipyard, shipbuilding activities accelerated, and the creation of the desired workforce by preventing illegal shipbuilding brought dynamism to the island.

\section{Main Actor in Shipbuilding Mütesellim of Rhodes Murâbıtzâde Cap- tain Hasan}

"Mütesellim" was responsible for collecting and sending the money and other revenues that the sanjak had to pay to the state treasury on time, and also had their powers because he was in the position of deputy of "beylerbeyi" or "sanjak bey" (Özkaya, 2006: 203). The most important officer in the region was Mütesellim Murâbıtzâde Captain Hasan. This person, who was held responsible for the construction of many galleons and frigates between $1787-1816$; he had earned the trust of the state with his hard work. Mütesellim Captain was not only personally responsible for the security of Rhodes Island but also, he was given the task of collecting "cizye" so that he could finance the ships. The captain's duties were renewed periodically. In the document dated 4 October 1790 (25 Muharrem 1205), which was the memorandum written to the captain and Grand Vizier Gazi Hüseyin Pasha, for Murâbıtzâde Gulami Captain Hasan from Rhodes, one of the Saliyaneli Swallow Captains, considering that he has been on duty for five years since he was able to complete the construction of the frigate with the

3 "Kantar" (scales) size varies by region and century, but weighs 56,452 grams $(56.5 \mathrm{~kg})$. 
length of 47 "zira" (35.62 meters) (Hinz, 1990: 68) and dominated the local structure, task of collecting the "cizye" and the title Mütesellim of Rhodes was given to him from March 1205 to Muharram 1206. Shipbuilding was requested to start immediately (Document-16). These duties were given to the person again in the next year. In the document dated 18 August 1792 (29 Zilhijce 1206), Murabitzade Captain Hasan, who was the captain of the frigate and Mütesellim of Rhodes, in addition to the frigate construction duty, on the condition of protecting the Rhodes Strait from pirates, the title of Mütesellim in 1207 was given with the bail of Selim Efendi, "the Kapı Kethüda" (Document-17, 18).

In the first document dated 13 December 1787 (3 Rebiülevvel 1202) sent to Müteselim Murâbitzâde Captain Hasan of Rhodes, 500 scales of raw iron were requested for the frigate being constructed in Rhodes; while it was reported that 400 scales irons were sent before; Chief Accountant also reported that 600 scales and 200 scales of raw iron had been given 3 times. Mehmet Cavuş was assigned to find tar and "zimmet" (money); it was also requested to provide boats for the application of this work (Document-19). Then, we see that the Central Istanbul wanted ships for the voyages to be made from the small shipyards, which were the shipbuilding centers. In the document dated April 29, 1788 (23 Recep 1202), in the official post sent to Abdülkadir the Voivode of Lemnos, as there was a possibility of an expedition to Moscow, landing a navy in the Black Sea came to the fore; it was requested that two swallow ships being constructed in Lemnos, Lesbos, Rhodes, Kuşadası and Peloponnese were completed and sent. For the frigate constructed by Murâbıtzâde Hasan Bey on Rhodes Island, an official document (şukka) was sent to "Kadi" of Rhodes (Document-20).

In the document dated 17 April 1791 (13 Şaban 1205), it was reported to the Chief Accountant that 10 thousand kurus the cost of the frigate, which he was responsible for the construction on Rhodes Island, was paid in advance by Murâbıtzâde Captain Hasan (Document-21). A year later, Mütesellim of Rhodes Murâbıtzâde Captain Hasan asked to send supplies, ammunition and money for the frigate that was being constructed in Rhodes. Caulking the ship's deck; the treasurer was informed to complete the wooden lining of the sides and to bring fire pumps and raw iron to the ship. The Imperial Arsenal was informed about sending a captain, a chief and

\footnotetext{
${ }^{4}$ The most common of the "Zira" was $54 \mathrm{~cm}$, and the one used in canal measurements was $145.6 \mathrm{~cm}$
} 
stagers from Istanbul to the ship whose construction was completed. While it was desired to provide the necessary convenience for the purchase of the steamboat required for the journeyman of the frigate from Alexandria; it was reported that this expense would be set off to the tax farmer (Document-22). 5000 kurus which was the cost of a piece of frigate ship to be constructed in Rhodes was sent to Murâbitzâde Captain Hasan from Cephâne-i Âmire (arsenal); it had been stated that 200 scales of raw iron were required. Previously, 28.391,5 kurus was sent and 2200 scales of raw iron were sent (Document-23). In the document dated 18 August 1792 (29 Zilhijce 1206), it was stated that 23.591,5 kurus and 1000 scales irons was sent for the construction of the frigate in Rhodes to Mütesellim of Rhodes Murâbıtzâde Captain Hasan. For the construction of the frigate, laborers were required to work diligently by combining night and day (Document24). A month later, the frigate "Zilhicce", which was constructed in Rhodes by Murâbıtzâde Captain Hüseyin, Mütesellim of Rhodes Island, was launched on the $25^{\text {th }}$ day. As seen in this example, frigates usually took between one and two years to construct. The date the shipbuilding was finished is actually the date when the new shipbuilding was started.

In the document dated 14 September 1792 (27 Muharram 1207), the construction of the frigate was just finished, it was requested necessary equipment such as the raw iron, timber and personnel such as carpenters, blacksmiths, workers for the construction of the other frigate, which was just started to be constructed, with a length of 47,5 "zira" (36 meters). He requested woodcutters, carpenters, drillers for the wood and blacksmiths; besides those he also requested 10 thousand kurus and 200 scales of iron. Again, 300 scales of iron nails (Mismar) were sent to Rhodes Island and it was requested that the wages required for the laborers be paid by Murâbıtzâde (Document-18). We also see that the tradesmen required for shipbuilding on the island were not enough because they went to other regions. Kapıcıbaşı Süleyman Bey, who constructed a galleon in Bodrum, was allowed to come to Rhodes to hire carpenters, caulkers and monthly workers, with the permission he received from the state, in the period from 1206 until the end of the year; in the notification made to Murabitzade Captain Hasan, the situation was written from The Imperial Arsenal to the Chief Accountant (Document-25, 26). In the document dated 19 October 1792 (3 Rebiülevvel 1207), Murâbıtzâde Captain Hasan paid the price of 10 thousand kurus for the cost of the frigate, which was being constructed in Rhodes with the length of 51 "zira" (38.5 meters) long. This time, an application was made 
to the Chief Accountant for the payment of 7500 kurus (Document-27). Two months later, it was ensured that the 10.000 kurus sent for the completion of the newly constructed frigate in the Rhodes area was sent by Hüseyin Çavuş, one of "Divanhane Çavuş" (official person who gives orders). It was reported by the Galleon "Nazır" (superintendent), Mütesellim of Rhodes Murabitzade Captain Hasan that the number of workers for the shipbuilding work was increased and that the ship would be completed with hard work day and night. According to the information given to the Kapudan Pasha by the architect it was reported that; the pocket belt would be fixed in 40 or 50 days, Hezz (stoppage) floors would be installed and the fore and stern stuffing would be started (Document-28). Murâbıtzâde Captain Hasan, who was very skillful in shipbuilding, was seen by the state in a different position compared to other shipbuilding managers around. While the captain was asked to return the remaining money from the ships whose constructions were completed to the state; we also see that the captain was given a task to build a new ship. In the document dated March 4, 1793 (21 Recep 1207), the captain was asked to send back the remaining 13.961,5 kurus from the expenses of the frigate he constructed last year, which costed 47.035,5 kurus and the other frigate with a length of 51 "zira", which was still under construction, costed 33.391.5 kurus. Since the frigate that the captain constructed in Rhodes was much better than the ones constructed in other areas, it was requested that the wages requested by the person be given without any reduction in order not to hinder his efforts (Document29). In the document dated 7 August 1793 (29 Dhul-Hijjah 1207), the necessary equipment for the ships to be constructed in the province were sent to their places; the same amount was provided to Murâbitzâde for the frigates with the length of 51 "zira" to be constructed in the Rhodes area, with the same amount given to Altıkulaç-zade El-hac Hüseyin Ağa for the galleons constructed in the Sinop area. In the year 1206, 32.500 kurus money, 900 scales of raw iron and 300 scales of nails (mismar) were given for the frigate with length of 51 "zira" that Murâbıtzâde had constructed. While the filling of the ship's head and stern was completed, the pocket belt consisting of 30-40 eyes was tried to be completed by working day and night. It was stated that the ship would be launched on the $24^{\text {th }}$ day of Ramadan (Document-30). In the document sent a month later, Tersane Emini Osman Bey (paymaster general) was informed that 300 scales of raw iron were sent for the frigate being constructed in Rhodes. It was requested that the 
iron be transported as soon as possible for the uninterrupted continuation of shipbuilding (Document-31).

With the completion of the ships, we see that new ships were constructed without any break. With the completion of the ship being constructed by Murâbıtzâde Captain Hasan, at the same time in the document dated February 1, 1794 (29 Cemazielahir 1208), it was planned to construct a frigate with a length of 53 "zira" (40.17 meters) again without wasting time. We see that shipbuilding works continued in other shipyards as well. We see that the Chief Accountant was asked how much money and iron (ahe) was given for the eight frigates and galleons which were constructed by Abdülkerim Ağa Voivode of the Lemnos "Divan"; Ömer Ağa, Mütesellim of the Menteşe Sanjak, one of the "Kapıcıbaşı" of the Dervish Lodge in Bodrum; Muratibzade Captain Hasan (Baykara Taşkaya, 2020: 159), the Mütesellim of Rhodes in Rhodes; Numan Bey from Inegöl in Gemlik; Osman Bey in Sultaniye; El-Hac Ali Ağa in Sinop; Kasap El-Hac Osman Ağa, in Erikli; Keleş Ahmet Bey, "Muhafız" of Sukhumi in Sukhum. While a fee of 20 thousand was paid to the three warehouses of Rhodes, 5000 for the galleon constructed in Gemlik, 10 thousand for the galleon in Sultaniye, 7500 kurus for the Sinop galleon; building "emins" were not paid; information was requested about this situation (Aydın, 2007: 36-37; Çırpan, 2020: 48). While the Rhodes galleon was planned to be launched in the month of Shawwal; it was decided to bring the necessary ammunition from "Dersaadet". The timber required for this work was requested from Cezraz (?) to be cut and brought to the site (Document-32).

In the document dated 17 July 1794 (18 Zilhijja 1208), it was stated that the frigate was finished in Rhodes, without giving its size. Murâbıtzâde Captain Hasan was informed that the construction of the galleon constructed in Köyceğiz was also awarded a contract, and that this ship was to be taken out of the Köyceğiz strait. Again, the construction of a frigate with the length of 53.5 "zira" ( 40.55 meters) had begun; while the remaining parts of this frigate were requested to be carried by boats; Captain Pasha reported that 10 thousand kurus timber and 300 scales of raw iron would be sent for the ship to be constructed and launched by the French architect (Document-33). On 5 August 1795 (19 Muharrem 1210), 500 scales of iron was given (Kallek, 2001: 317-320) for two ships in Gemlik, Mytilene, Bodrum and also 10 thousand kurus money was transferred. It was requested to provide timber and iron to those in Lemnos, to provide the necessary preparations for launching the frigate, in the holy month of Ramadan as soon as possible 
which was constructed under the leadership of Murâbıtzâde Hasan in Rhodes, where the cannons and awnings were installed.

In the document dated 3 May 1796 (25 Shawwal 1210), the frigate constructed by Murâbıtzâde Captain Hasan in Rhodes Island was brought to Istanbul fully equipped for launch in Shawwal, it had been requested that the captain and the stagers be sent to Istanbul to The Imperial Arsenal and it was also requested that 120 sailors be sent to Rhodes with 42 kurus each for the time being. It was requested that the budget that would cost 5006 kurus for the consolidation of the workers in the Greek Islands of Rhodes should be paid as the galleon worker's expense; it had been reported that this work was ordered and written in Greek by Captain Pasha (Document34). The frigate on the island of Lemnos was requested to be finished, hence the captain and his rowers were requested to be brought in. The timber and laborers for the ships of the Lemnos and Bodrum Districts were obtained from the surrounding districts. While it was reported that budget and iron were required for the construction of these ships; it was noted that where there was "bina emini", the delivery of "akces" written as debit was not carried out. In addition, it was reported that the construction of the three-bay galleon in the provincial shipyards was not considered very warmly in the document; in Rhodes, it was requested to send 35.000 kurus and 5000 scales of raw iron for the three-bay galleon, which was 64 "zira" (43.52 meters) long, owned by Muratibzade Captain Hasan, Mütesellim of Rhodes. In total, 3 loads of 3914 kurus were spent on the costs of these ships; 3480 scales of iron were requested from the shipyard. 10,480 scales of equipment were sent as iron and nails from Cephane-i Âmire. In addition, 3 loads of 63.797 kurus were spent for the completion of the ships; another 8020 scales of iron were requested to be sent for the need (Document-35).

We see that regular payments were made to employees during a period when the shipbuilding process was underway. In the document dated 13 May 1801 (29 Zilhijce 1215), it was stated that in the census sent to Murâbıtzâde Hasan in Rhodes, the salaries of 37.800 kurus were sent by Grand Vizier Hüseyin Pasha to be given to the navy soldiers who served on the galleons, frigates and corvettes that were stationed in the winter quarters; it was requested that the money be spent on eligible ships (Document-36).

Captain Hasan's construction activities continued at the beginning of the $19^{\text {th }}$ century. In the document dated June 26, 1804 (17 Rebiul before 1219), Murâbıtzâde Hasan Bey, after launching the galleon, the equipment like felenk and sled for launching another ship, the frigate named "Bahri 
Amik", was sent to Bodrum pier from The Imperial Arsenal. Çavus Hadimzade Osman Bey provided the large wooden boards and pine wards, Turkish pine timber from Mount Ida and sent them to Istanbul. The tip of the captain and his staff, which was 1700 kurus, and the cost of 3400 kurus for the crew of 22 people required for the captain and the chief were written to the Chief Accountant (Document-37). The book of expenses incurred was also 1725 kurus in total.

\begin{tabular}{|l|l|l|}
\hline Employees & Number (nefer) & Fee \\
\hline Reis-i Evvel & 1 & 40 \\
\hline Badban-ı Sani & 1 & 25 \\
\hline Reis-i Sani & 1 & 25 \\
\hline Reis-i Salis & 1 & 20 \\
\hline Ser Tulleb & 1 & 25 \\
\hline Hoca & 1 & 25 \\
\hline Ağa-yı Sefine & 1 & 20 \\
\hline Neferatı Gedikliyan & 23 & 1245 \\
\hline Süvari Kaptan & 1 & 200 \\
\hline Mülazım Kaptan & 1 & 100 \\
\hline & 32 & 1725 \\
\hline
\end{tabular}

Table 1. Tips of the employees involved in the launch of the Bahri Amik frigate (Document-38).

In order for the people assigned in shipbuilding to do this job properly, the necessary economic power had to be provided to the individuals. We see that the "cizye" income was also allocated for shipbuilding. In the document dated September 3, 1807 (29 Cemazielahir 1222), 50.00 kurus was given annually from the Rhodes "cizye" for the frigate constructed by $\mathrm{Mu}$ tasarrıf of Rhodes, Murâbıtzâde Captain Hasan. The same amount of receipt notes submitted for 1222 (Document-39). On November 17, 1809 (February 9, 1224), a notice was sent to the Chief Accounting Officer of The Imperial Arsenal to cut the 4200 continental timber required for the frigate being constructed in Rhodes from the Rhodes Mountains to be used for launching with the completion of the ship; also 5200 kurus were sent for the expenses of the job (Document-40). Exactly two years later, this frigate was finished; Mutasarrif of Rhodes Hasan requested a crew to launch the frigate. The payment of 1292,5 kurus 12 money for food and grain, which was the fee for 
the appointments of the two captains and 24 stagers who were brought from Istanbul, and the payment of the appointment money that the frigate's cavalryman Canım Captain Mustafa received from Hüseyin Bey was written to the Chief Accountant; registration of the ship at the shipyard was done (Document-41).

The shipbuilding activities of Mutasarrıf of Rhodes Hasan Bey, continued without slowing down. In the document which was sent by Mutasarrif of Rhodes Captain Hasan dated 26 November 1812 (21 Zilkade 1227), it was reported that he was dealing with the establishment and equipping of the frigate constructed in Rhodes. In the time Sakir Hasan Bey was working on completing the frigate and launching it to the sea; Arnavut Captain Ibrahim was asked to find 50 workers who would work in shipbuilding. The daily food of the 40 wardens assigned to the ship was provided by themselves (Document-42). In the document that came after a one year, Paymaster General iftihar Seyid Mehmet Ağa was informed about the six ships decided to be constructed. 49 "zira" (37.14 meters) frigate was constructed by Mutasarrıf of Rhodes Hasan Bey, in Rhodes, another 49 "zira" frigate was constructed by Kavizade İbrahim Ağa in Sinop and the construction of a 59.5 "zira" (45.10 meters) galleon in Bodrum by Voivode of İmir Hacı Mehmet Ağa was reported to the Chief Accountant (Document-43). In the document dated March 20, 1813 (17 Muharram 1228), it was requested that the ships be constructed at least 49 "zira" long. The records of these ships, which were reported to the Chief Accountant, were kept by The Imperial Arsenal (Document-44).

Providing food for those who worked in shipbuilding and for those who sailed on the ships was a major problem. The food usually given to workers was sea biscuit. On May 20, 1804 (May 9, 1219), it was requested that gunpowder and sea biscuit be delivered to Mediterranean ships which were Murâbıtzâde Captain Hasan's frigate and Captain Mustafa's swallow ship from Rhodes, and their receipts to be sent; the request was repeated in the document (Document-45) ten days later. An official letter was written by Paymaster General Yusuf Bey to the Chief Accounting about 500 scales of sea biscuit and 20 scales of gunpowder to be given to the frigate of $\mathrm{Mu}$ tasarrıf of Rhodes Murâbıtzâde Hasan Bey and 120 scales of sea biscuit and 30 scales of gunpowder to be given for the swallow ship of Mustafa Captain of Rhodes (Document-46). It was reported that only 30 of the 367 tons of gunpowder requested for Rhodes Castle were sent via Black Sea, it was requested that the goods sent be stored by the soldiers. Gallipoli Bakery be- 
came an important place for providing food to many cruise ships and many shipbuilding places in the Mediterranean and Aegean Seas. On October 8, 1832 (October 13, 1248), a frigate constructed in Rhodes and ships in need of repair arrived in front of Chios Island to receive supplies and ammunition from the "Donanma-yı Humâyûn" (Imperial Navy). Some ships arriving in the Algerian Bahri Sefid Strait reported that their six-month supplies given by the Donanma-yı Humâyûn were running out. While food was provided from the Gallipoli Bakery; the ships that arrived in Samatya at their last stop returned to the Bahri Sefid Strait and entered the inland sea on the sides of Bozcaada and Island of Lemnos after the inspection and research. After giving information about their arrival in the Mediterranean Strait; they expected to determine their next route (Document-47). As it can be seen, the Gallipoli Bakery was an important base that provides supplies to ships on the cruise and places that build ships.

Although they provided a lot of benefits during the construction of the ship, we see that the state did not take enough care of its officials in the event of their deaths. It is very sad that even the remaining expenses of the ships constructed, were covered by the inheritance of those people. In the document dated January 22, 1816 (21 Safer 1231), Tersane Kethüdası Yusuf Bey(chamberlain), who was appointed as Rhodes Mutasarrif to complete the frigates, which were started with the permission taken during the ages Mutasarrıf of Rhodes Murâbıtzâde Hasan Bey, in his letter sent to the Sublime Porte (Babı Ali), he requested that a chief officer and an officer be sent to capture the deceased captain's heritage. In the incoming documents he informed that Captain Hasan's unfinished ships would not be completed and the remaining ships would be suspended; it was requested that the construction not be interrupted and the money required for the construction covered from the Murâbıtzâde estate (Muhallefat) (Document-48). Mutasarrıf of Rhodes, Murâbıtzâde Captain Hasan, became a statesman with great services to the state by acting as a captain who understood the sea, knew Rhodes and its surroundings. Admired by the state for his achievements in shipbuilding, the captain was personally responsible for the completion of 8 frigates during his tenure.

\section{Mutasarrif of Rhodes Yusuf Bey}

In the Ottoman administrative organization "mutasarrif" means "a person who holds any office, duty or official position, who makes use of it". This term was also used to distinguish between a deputy and a title holder and it was often used in the sense of a person who owned a manor, has and 
"timar". Those who were actually appointed to the position of "kadi" in the scientific organization were also referred to as "mutasarrif" The fact that the word had acquired the meaning of "administrator sent to the sanjak or liva" was related to the developments that had occurred since the beginning of the $17^{\text {th }}$ century (Örenç, 2006: 377). Between 1816 and 1828, the Mutasarrif of Rhodes Yusuf Bey, who was engaged in shipbuilding, provided very useful services to the state.

In the document dated 19 June 1816 (23 Recep 1231), the two corvettes (Güleryüz, 2004: 32) under construction in Benderereğli were finished and they were launched on time as it was planned. A frigate with the length of 51 "zira" (38.5 meters), a corvette being constructed in Biga Kemer was launched; in the same way, 14 cannons were placed on the rough side of a frigate being constructed by Mutasarrıf Yusuf Bey with a length of 53 "zira" (40.17 meters) on Rhodes Island; when the frigate was finished in Rhodes, it was launched into the water. Again, another frigate planned to be constructed on the island immediately (Document-49).

The shipbuilding works of Murâbıtzâde Hasan Bey were also transferred to Yusuf Bey. We see that the construction of the 53 "zira" (40.17 meters) large frigate called "Bahr-i Zafer" was continued by Yusuf Bey. In the document dated January 26, 1817 (8 Rebiül Evvel 1232), it was requested that 15 thousand kurus from Murâbıtzâde Hasan Bey's account be sent to Istanbul through Abdulkadir Efendi for the frigate that Mutasarrif Yusuf Bey was assigned to build in Rhodes. Since it was known that Murâbıtzâde Hasan Bey owed 27 thousand kurus to Darphane-i Âmire (Imperial Mint); only 15 thousand kurus of this money was demanded. The income from the foundations of the Haremeyni Şerif Nezareti El-hac Ibrahim Pasha, consisting of the gardens, fields, cellars, mansions, water wells and households on Rhodes Island outside the Castle, was rented and the income of those places was given to the state. Ismail Refet Efendi, one of the teachers of Divan-I Hümayun (Imperial Council), who was "mütevelli" of the foundation, sent a request to "Rikab-ı Hümayunu Şahane"; if the foundation also agreed to sell this place to Yusuf Bey, it requested that its income, which is 12.500 kurus that was the equivalent price, be sent to The Imperial Arsenal (Document-50). At the end of the same year, the galleon made in Rhodes was completed and sent to Dersaadet; the cost book containing all expenses incurred, the cost of cutting timber and the expenses of the craftsmen of the great frigate sent to Istanbul, which was made by Mutasarrif of Rhodes Yusuf Bey, was presented. It was reported that more than 200.000 kurus 
accumulated for the ship's construction operations. Although convenience was shown in relation to the situation as Murâbitzâde Hasan Bey's service was over, it was also thought that 30 thousand kurus would be used on later ships. Apart from the debt, the Shipyard Treasury sent 60 thousand kurus to the person (Document-51). In the document dated March 12, 1818, the Chief Accountant was asked to provide 14.268 kurus, which was the cost of the frigate. 48.000 kurus was given; it was reported that 114.720 kurus would be given, in addition it was reported that 60.200 kurus was sent from The Imperial Arsenal apart from the money requested for 66.720 kurus (Document-52).

New shipbuilding efforts continued with larger frigates. In the document dated 11 June 1820 (29 Şaban 1235), instead of the frigate launched in Rhodes, the construction of the 53,5 "zira" (40.55 meters) frigate named "Mazhar-I Tevfik" was started by Yusuf Bey, who was "Ümera-i Derya" and Mutasarrif of Rhodes Sanjak, the necessary notification was made to the Chief Accountant (Document-53). On the same date, Mutasarrif of Rhodes Yusuf Bey, received 200 kurus per diem for Mühendis Captain Mustafa to work in the construction of the frigate; when the construction of the ship started, it was ensured that 100 kurus monthly and 35 kurus from the arrival of the ship to the island. Architect Anayoste was given 150 kurus per diem and 100 kurus monthly and 25 kurus for assignment. It was decided to give salary to the personnel who would work for the shipbuilding process at the place designated by the shipyard (Document-54). The most important food for shipbuilding workers was sea biscuit. In some cases food supplied from nearby districts. From the information provided for the frigate constructed by the Mutasarrif of Rhodes Yusuf Bey, we can access information about how the food was provided from the Ümerayı Bahriye. 500 scales of sea biscuits was given at certain periods every year, for the year 1235 it was reported that sea biscuit loaded on ships from Gallipoli Bakery and delivered to Paymaster General Hacı Halil Terkan (Document-55). One year later from the ship's construction process began, a total of 30 thousand kurus was requested for the supply of timber and labor costs in the decision given by the Kadi of Rhodes for the completion of the frigate. The status was written by the chief engineer to The Imperial Arsenal and the Chief Accounting Officer (Document-56). In the first month of 1821, it was ensured that the wages and appointments of the engineers, captains, "hocas" and staff who would take part in the construction, maintenance and equipping of the frigate were paid from the Shipyard Treasury. A total of 11.848 kurus expense 
was incurred from The Imperial Arsenal to the Chief Accountant for this work (Document-57). In the document dated March 30, 1822 (7 Recep 1237), the book of the equipment necessary for this frigate, which was being constructed on the Rhodes dockyard, was sent by a Nemçe Ship from the shipyard (Document-58). Thus, the construction of the ship was completed in a period of nearly two years.

\begin{tabular}{|l|c|}
\hline Equipment & Piece \\
\hline Alatı Cedid (New instruments) (Scale 10) & 10 \\
\hline Caru(b) Medan(?) (Mop, Broom) Pulley & 20 \\
\hline Mahab Calking Tool (Scale 5) & 5 \\
\hline Ahen Hame (Raw Iron) & 500 \\
\hline Alatı Mustamil(Various Tools) (Scale 10) & 10 \\
\hline Salb Sehav Mevad (Scaffold) & 4 \\
\hline Alatı Mustamil( Scale) & 10 \\
\hline Takım fırkate (The Compression Tool) & 7 \\
\hline Rope ,Shovel, Frigate & 40 \\
\hline Ahen Minkir Sekal (Iron Tools) & 3 \\
\hline Alatı Cedid Mübaya(The Purchased Tool) & 3 \\
\hline Mirbat Fırkate(Place of fixation) & 4 \\
\hline Iron Clamp Vise (Iron Vise) & 4 \\
\hline Iron Glazed Barrel & 10 \\
\hline Alatı cedid Mübayaa (New Tools Purchased) & 5 \\
\hline
\end{tabular}

Table 2. Equipment of the Frigate was Launched on the Island of Rhodes on March 30, 1822.

Shipbuilding activities on Rhodes Island ended with the establishment of Fethiye Shipyard. Suda (Crete Island) and Basra shipyards were new shipyards created with Fethiye (Panzac, 2020: 391).

\section{Conclusion}

With the start of the shipbuilding works in the shipyard, the economic revival that the people wanted was achieved. The largest type of ship constructed on Rhodes Island due to the small port was a frigate, which was a medium-sized warship. With the arrangements made in the port, the galleon, which was a larger shipbuilding, came to the fore. Ships were usually 
constructed by the rulers of the region. The two most important elements for shipbuilding were the personnel to be employed and the equipment to be used in the construction of the ship. These two important issues were intertwined. The captain of the ship was held responsible for carrying out these two works.

The most influential state official in the region that constructed ship was the Mütesellim Murâbıtzâde Captain Hasan. The state trusted this person, who also took on several duties within the state, and the galleons and frigates constructed by the person for the state were successfully completed. After the captain's death, his estate was confiscated by the state; debts to the state were collected. The Mütesellim Yusuf Bey served at the state level after the Mütesellim Murâbıtzâde Captain Hasan; we see that this person also completed the construction of many frigates. These two officers, who were personally responsible for the construction of many ships in different periods, had successfully completed their construction activities. As a result, in our article, on the trail of Ottoman archival documents, we tried to explain construction activities in Rhodes, a large-scale island, with the maximum capacity that can be done with the help of the assistance received from Istanbul by the ships in need of the Navy. Rhodes Shipyard, one of the newly established provincial shipyards as a reflection of the reform movements that gained momentum in the maritime field during the reign of Selim III, was one of the important bases that built galleons and frigates that the Ottoman navy needed in the shipbuilding works from the first half of the $18^{\text {th }}$ century to the beginning of the $19^{\text {th }}$ century. We have tried to explain, what type of materials used when building frigate type ships in the and with what organization they were built by which officials; and how they were delivered to Istanbul during the shipment stage. While describing this process in our article, we also tried to mention about the social and economic events affecting shipbuilding.

\section{References}

Arı, Kemal (2009). "Yelkenliden Buharlıya Geçiş”. Türk Denizcilik Tarihi 2. Ed. Zeki Arıkan \& Lütfü Sancar. İstanbul: Deniz Müzesi, 125-145.

Arıkan, Sema (ed.) (1993). III. Selim'in Sırkâtibi Ahmed Efendi Tarafından Tutulan Rûznâme. Ankara: TTK.

Aydın, Y. Alperen (2007). Osmanlı Denizciliği (1700-1770). PhD Thesis. İstanbul: Istanbul University Institute of Social Sciences. 
Batmaz, Şakir (2009). "Il. Abdülhamit Dönemi Osmanlı Bahriyesi”. Türk Denizcilik Tarihi 2. Ed. Zeki Arıkan \& Lütfü Sancar. İstanbul: Deniz Müzesi, 159-173.

Baykara Taşkaya, Arzu (2020). "Akdeniz'de Bir Geçit: Rodos Karantinası”. Antik Çağdan Günümüze Tarih Yazıları. Ed. Metin Kopar. Ankara: IKSAD Publishing House, 147-187.

Beydilli, Kemal (1995). Türk Bilim ve Matbaacılık Tarihinde Mühendishane, Mühendishane Matbaası ve Kütüphanesi (1776-1826). istanbul: Eren.

Bostan, İris (1992). "Osmanlı Bahriyesinde Modernleşeme Hareketleri 1, Tersane'de Büyük Havuzun İş̧ası (1794-1800)". 150. Yılında Tanzimat. Ed. Hakkı Dursun Yıldız. Ankara: TTK, 69-100.

Bostan, İris (1999). "XVI-XVII. Yüzyıllarda Osmanlı Tersaneleri ve Gemi İnşa Teknolojisi”. Osmanlı Ansiklopedisi, Vol.6. Ankara: Yeni Türkiye, 620629.

Bostan, İdris (2004). “Kadırga'dan Kalyon'a XVII. Yüzyılın íkinci Yarısında Osmanlı Gemi Teknolojisinin Değişimi”. Osmanlı Araştırmaları, 24: 6586.

Bostan, İdris (2005).Kürekli ve Yelkenli Osmanlı Gemileri. İstanbul: Bilge.

Bostan, İdris (2009). "Kalyonun Yükselişi ve Akdeniz'de Osmanlı Donaması (XVIII. Yüzyıl)”. Türk Denizcilik Tarihi 2. Ed. Zeki Arıkan \& Lütfü Sancar. İstanbul: Deniz Müzesi, 15-27.

Bostan, İdris (2020). "Osmanlılar Niçin Kalyon İnşasından Bir Süre İçin Vazgeçtiler? (1656-1682)". Tarih Dergisi, 71: 223-238.

Cabi Ömer Efendi (2003). Câbi Tarihi, Vol.1. Ankara: TTK.

Cezar, Mustafa (ed.) (1959). Mufassal Osmanlı Tarihi, Vol.3. İstanbul. Tan.

Choiseul-Gouffier, Auguste de (1782). Voyage pittoresque de la Grèce 1752, 1817. Paris: J. Blaise.

Cipolla, Carlo M. (2003). Yelken ve Top. Trans. Aslı Kayabal. İstanbul: Kitabevi.

Çetin, Birol (2002). "Osmanlı İmparatorluğu'nda Askeri Teknolojinin Takibi (1700-1900)". Türkler Ansiklopedisi, Vol.6. Ankara: Yeni Türkiye, 812821.

Çırpan, Mustafa (2020). “Osmanlı Devleti’nde Gemi Tipleri ve Gemi Kazaları ile ilgili Değerlendirmeler”. GiDB Dergi, 19: 41-58. 
Erkal, Mehmet (1993). "Cizye”. TDV islam Ansiklopedisi, Vol.8. İstanbul: TDV, 42-45.

Gencer, Ali ihsan (2001). Bahriye'de Yapılan Islahat Hareketleri ve Bahriye Nezareti'nin Kuruluşu (1789-1867). Ankara: TTK.

Guilmartin, John, F. (2010). Kalyonlar ve Kardırgalar. Trans. Ali Özdamar. İstanbul: Kitabevi.

Güleryüz, Ahmet (2004). Kadırgadan Kalyona Osmanlıda Yelken: Mikyas-ı Sefain. İstanbul: Denizler Kitabevi.

Hinz, Walther (1990). “islam'da Ölçü Sistemleri”. Trans. Acar Sevim. Türklük Araştırmaları Dergisi, 5: 1-82.

İşbilir, Ömer (2016). "Kalebend". TDV İslam Ansiklopedisi, Vol.Ek -2. İstanbul: TDV, 5-7.

Kallek, Cengiz (2001). "Kantar”. TDV İslam Ansiklopedisi, Vol.24. İstanbul: TDV, 317-320.

Melling, Antoine I. (1819). Voyage pittoresque de Constantinople et des rives du Bosphore 1763-1831. Paris.

Örenç, Ali Fuat (2006). "Mütesellim". TDV İslam Ansiklopedisi, Vol.31. İstanbul: TDV, 377-379.

Özkaya, Yücel (1985). Osmanlı Imparatorluğu'nda Ayanlık. Ankara: TTK.

Özkaya, Yücel (2006). "Mütesellimlik". TDV isslam Ansiklopedisi, Vol.32. İstanbul: TDV, 203-204.

Panzac, Daniel (2009) . "Osmanlı Donanması, Başlangıcından Nizam-ı Cedid'e Kadar (14.-18. Yüzyıllar)". Osmanlı Donanmasının Seyir Defteri: Gemiler, Efsaneler, Denizciler. Ed. Ekrem Işın. İstanbul: Pera Müzesi, 1631.

Panzac, Daniel (2020). Osmanlı Donanması(1572-1923). Trans. Ahmet Maden \& Sertaç Canpolat. İstanbul: iş̧ Bankası.

Uzunçarşılı, i. Hakkı (1988).Osmanlı Devleti'nin Merkez ve Bahriye Teşkilatı. Ankara: TTK.

Ünal, A. Afşin (2002). "XVI. ve XVII. Yüzyıllarda Cezayir-i Bahr-i Sefid (Akdeniz, Ege Adaları) ya da Kapudan Paşa Eyaleti”. Erciyes Üniversitesi Sosyal Bilimler Enstitüsü Dergisi, 12: 251-261.

Ünen, Uğur (2013). XVIII. Yüzyılda Osmanlı idaresinde Rodos. Master Thesis. Aydın: Adnan Menderes University Social Sciences Institute. 
Zorlu, Tuncay (2009). "IIl. Selim ve Osmanlı Deniz Gücü”. Osmanlı Donanmasının Seyir Defteri: Gemiler, Efsaneler, Denizciler. Ed. Ekrem Işın. İstanbul: Pera Müzesi, 32-44.

\section{Archive Documents}

Document-1: BOA, A. JMKT. 144, 71

Document-2: BOA, A. JMKT.UM. 41, 79

Document-3: BOA, C.BH. 206, 9620

Document-4: BOA, C.BH. 116, 5635

Document-5: BOA, C.BH. 229, 10660

Document-6: BOA, C.BH. 183, 8593

Document-7: BOA, C.BH. 155, 7356

Document-8: BOA, C.BH. 247, 11461

Document-9: BOA, C.BH. 7, 309

Document-10: BOA, HAT, 1253, 48479

Document-11: BOA, HAT, 889, 39276

Document-12: BOA, C.BH. 251, 11645

Document-13: BOA, C.BH. 61, 2896

Document-14: BOA, HAT, 573, 28093

Document-15: BOA, HAT, 611, 29987

Document-16: BOA, C.BH. 135, 6540

Document-17: BOA, AE.SSLM.III, 44, 2539

Document-18: BOA, AE.SSLM.III, 44, 2541

Document-19: BOA, C.BH. 272, 12561

Document-20: BOA, C.BH. 208, 9720

Document-21: BOA, C.BH. 91, 4352

Document-22: BOA, C.BH. 95, 4559

Document-23: BOA, C.BH. 19, 902

Document-24: BOA, AE.SSLM.III, 209, 12407

Document-25: BOA, C.BH. 21, 1028

Document-26: BOA, C.BH. 37, 1744

Document-27: BOA, C.BH. 245, 11351

Document-28: BOA, C.BH. 173, 8159

Document-29: BOA, C.BH. 219, 10197

Document-30: BOA, AE.SLM.III, 177, 10611 
Document-31: BOA, C.BH. 194, 9089

Document-32: BOA, C.BH. 114, 5525

Document-33: BOA, C.BH. 33, 1553

Document-34: BOA, C.AS, 667, 28011

Document-35: BOA, C.BH. 73, 3489

Document-36: BOA, AE.SSLM.III, 341, 19650

Document-37: BOA, C.BH. 5,234

Document-38: BOA, C.BH. 145, 6956

Document-39: BOA, C.BH. 268, 12353

Document-40: BOA, C.BH. 272, 12536

Document-41: BOA, C.BH. 120, 5806

Document-42: BOA, HAT, 1225, 47861

Document-43: BOA, C.BH. 125, 6065

Document-44: BOA, HAT, 1521, 14

Document-45: BOA, C.BH. 138, 6679

Document-46: BOA, C.BH. 141, 6806

Document-47: BOA, HAT, 351, 19832

Document-48: BOA, C.BH. 205, 9592

Document-49: BOA, C.BH. 178, 8356

Document-50: BOA, C.BH. 21, 1014

Document-51: BOA, C.BH. 107, 5186

Document-52: BOA, C.BH. 99, 4788

Document-53: BOA, C.BH. 112, 5419

Document-54: BOA, C.BH. 275, 12677

Document-55: BOA, C.BH. 222, 10308

Document-56: BOA, C.BH. 1, 25

Document-57: BOA, C.BH. 49, 2338

Document-58: BOA, C.BH. 61, 2894

The following statements are made in the framework of "COPE-Code of Conduct and Best Practices Guidelines for Journal Editors":

Ethics Committee Approval: Ethics committee approval is not required for this study.

Declaration of Conflicting Interests: The author has no potential conflict of interest regarding research, authorship or publication of this article. 